\title{
Reduction of platelet aggregation induced by euglycaemic insulin clamp
}

\author{
K. Hiramatsu, H. Nozaki and S. Arimori \\ Department of Internal Medicine, School of Medicine, Tokai University, Isehara, Kanagawa, Japan
}

\begin{abstract}
Summary. To examine the effect of serum insulin independent of the level of blood glucose in vivo on platelet aggregation in healthy individuals, a euglycaemic insulin clamp was applied up to $4 \mathrm{~h}$. During the clamp, blood glucose at $5.0 \mathrm{mmol} / \mathrm{l}$ and insulin levels at $100 \mu \mathrm{U} / \mathrm{ml}$ were maintained. Blood samples were drawn before, 2 and $4 \mathrm{~h}$ after the start of the insulin clamp. The platelet aggregation induced by $1 \mu \mathrm{mol} / 1$ and $2 \mu \mathrm{mol} / 1$ ADP, $1 \mu \mathrm{g} / \mathrm{ml}$ collagen and $2.7 \mu \mathrm{mol} / 1$ epinephrine was measured in the blood samples. Platelet aggregation induced by adenosine diphosphate, collagen and epinephrine in the $4 \mathrm{~h}$ sample was significantly reduced from the pre-clamp value of $8.4 \%$ to $3.9 \%(p<0.05)$,
\end{abstract}

$26.2 \%$ to $7.0 \%(p<0.01)$ and $31.8 \%$ to $9.1 \%(p<0.01)$, respectively. On the other hand, when the same individuals were infused with physiological saline and blood glucose $(4.4 \mathrm{mmol} / \mathrm{l})$ and insulin level $(10 \mathrm{mIU} / \mathrm{l})$ were kept within normal values, there was no difference between the values of induced platelet aggregation in samples drawn before and during the insulin infusion. It was concluded that hyperinsulinaemia reduces platelet aggregation in vivo when euglycaemia was maintained.

Key words: Insulin, platelet aggregation, euglycaemic clamp.
Many studies have demonstrated that platelet aggregation is often enhanced in diabetes mellitus and may lead in part to the development of micro- and macroangiopathy $[1,2]$. It has been reported that the hyperaggregation of diabetic platelets may be reversed following insulin treatment of a few weeks or months [3-5]. It has been proposed that either the high serum level of insulin, regardless of the level of blood glucose, reduces the platelet aggregation or the improvements of blood glucose and plasma lipid levels reduce the platelet aggregation. To find out which of these factors reverses hyperaggregation, we determined the short-term in vivo effect of hyperinsulinaemia on platelet aggregation in healthy individuals while maintaining normal glucose levels by the euglycaemic insulin clamp technique [6].

\section{Subjects and methods}

\section{Subjects}

Nine healthy males, aged 25-35 years, were used. Informed consent was obtained from all subjects.

\section{Insulin clamp}

After an overnight fast, the euglycaemic insulin clamp was applied and employed as described by DeFronzo et al. [6]. Insulin and $20 \%$ glucose were administered via an indwelling antecubital vein catheter. Porcine monocomponent Actrapid insulin (Novo Co., Bagsvaerd, Denmark) was diluted with isotonic saline to a concentration of $300 \mathrm{mU} / \mathrm{ml}$. Two $\mathrm{ml}$ of the subject's blood was added to $50 \mathrm{ml}$ of the insulin infusate in order to prevent absorption of insulin to the plastic surfaces. A 10 min priming infusion was followed by constant infusion to obtain hyperinsulinaemia for a duration of $230 \mathrm{~min}$. The $20 \%$ glucose infusion was started at 4 min after the start of the insulin infusion. The whole blood glucose level was monitored at $5 \mathrm{~min}$ intervals using a glucose monitor (SMG-IIA, Nikkiso Co., Tokyo, Japan), and euglycaemia was maintained by a variable infusion of $20 \%$ glucose. The glucose infusion was continued for $30 \mathrm{~min}$ after the termination of the insulin infusion. Blood samples for the determination of the levels of serum insulin, triglyceride, free fatty acid and total cholesterol as well as for platelet aggregation were drawn prior to the start of the clamp, and 2 and $4 \mathrm{~h}$ after the start of the clamp, from a separate unwarmed antecubital vein. Effectiveness of the euglycaemic clamp was determined by the coefficient of variation of glucose and insulin levels. The mean coefficient of variation for preinfusion, $2 \mathrm{~h}$ and $4 \mathrm{~h}$ blood glucose levels was $19.8 \%, 27.7 \%$ and $25.8 \%$, and for insulin levels $23.2 \%, 28.9 \%$ and $22.9 \%$. During control experiments, on another day, the same individuals were infused with $0.9 \%$ normal saline with rate and amount equivalent to the $20 \%$ glucose solution as measured by changes in hematocrit and plasma albumin levels. 
Table 1. Effect of saline infusion and insulin clamp on blood glucose, insulin, triglyceride, free fatty acid and total cholesterol levels

\begin{tabular}{|c|c|c|c|c|c|c|c|}
\hline & \multicolumn{3}{|l|}{ Saline } & \multicolumn{4}{|l|}{ Insulin } \\
\hline $\begin{array}{l}\text { Blood glucose } \\
(\mathrm{mmol} / 1)\end{array}$ & $\begin{array}{r}4.39 \\
\pm \quad 0.42\end{array}$ & $\begin{array}{r}4.45 \\
\pm 0.23\end{array}$ & $\begin{array}{r}4.77 \\
\pm 0.36\end{array}$ & $\begin{array}{r}4.23 \\
\pm 0.83\end{array}$ & $\begin{array}{r}5.04 \\
\pm 1.39\end{array}$ & & $\begin{array}{l}5.23 \\
1.37\end{array}$ \\
\hline $\begin{array}{l}\text { Immuno-reactive insulin } \\
(\mu \mathrm{U} / \mathrm{ml})\end{array}$ & $\begin{array}{r}10.1 \\
\pm \quad 2.6\end{array}$ & $\begin{array}{r}9.5 \\
\pm 2.1\end{array}$ & $\begin{array}{r}8.4 \\
\pm 1.9\end{array}$ & $\begin{array}{r}9.9 \\
\pm 2.2\end{array}$ & $\begin{array}{r}97.2 \\
\pm 28.1\end{array}$ & & $\begin{array}{l}04.5 \\
24.0\end{array}$ \\
\hline $\begin{array}{l}\text { Free fatty acid } \\
(\mathrm{mEq} / \mathrm{l})\end{array}$ & $\begin{array}{r}0.58 \\
\pm 0.29\end{array}$ & $\begin{array}{r}0.55 \\
\pm 0.25\end{array}$ & $\begin{array}{r}0.57 \\
\pm 0.13\end{array}$ & $\begin{array}{r}0.59 \\
\pm 0.31\end{array}$ & $\begin{array}{l}0.24^{b} \\
\pm 0.16\end{array}$ & \pm & $\begin{array}{l}0.17^{\mathrm{c}} \\
0.14\end{array}$ \\
\hline $\begin{array}{l}\text { Total cholesterol } \\
(\mathrm{mmol} / 1)\end{array}$ & $\begin{array}{r}4.58 \\
\pm \quad 0.36\end{array}$ & $\begin{array}{r}4.42 \\
\pm 0.41\end{array}$ & $\begin{array}{r}4.39 \\
\pm 0.45\end{array}$ & $\begin{array}{r}4.74 \\
\pm 0.82\end{array}$ & $\begin{array}{r}4.33 \\
\pm \quad 0.73\end{array}$ & \pm & $\begin{array}{l}4.35 \\
0.75\end{array}$ \\
\hline
\end{tabular}

All values are shown as mean $\pm \mathrm{SD} .{ }^{\mathrm{a}} p<0.02,{ }^{\mathrm{b}} p<0.01,{ }^{\mathrm{c}} p<0.005$ versus pre-infusion

Table 2. Effect of saline infusion and insulin clamp on platelet aggregation in healthy subjects

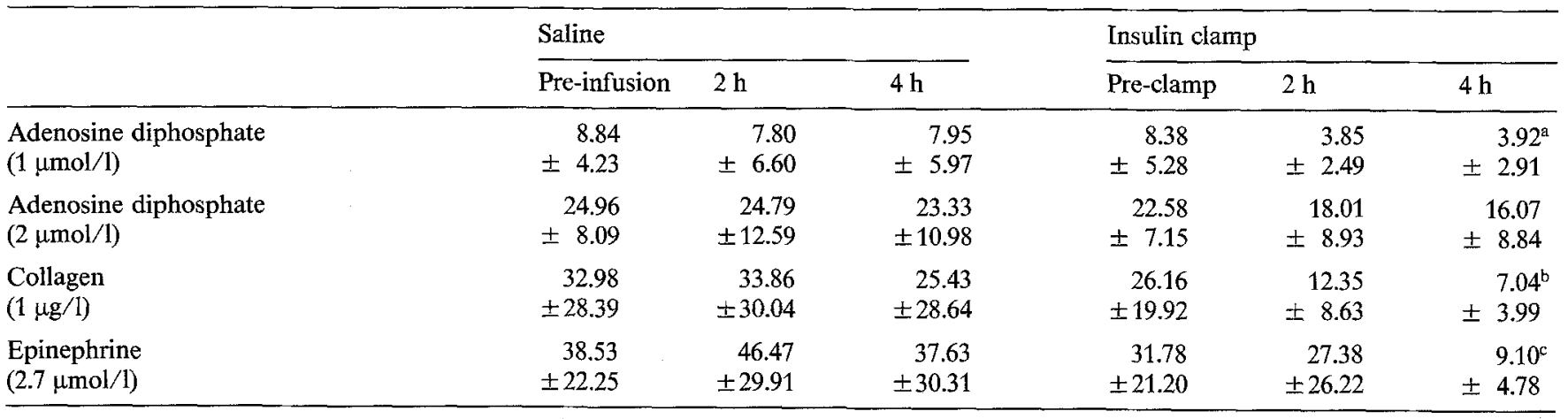

All values are expressed as mean \pm SD. ${ }^{a} p<0.05 ;{ }^{b} p<0.02,{ }^{c} p<0.01$ versus pre-infusion

\section{Platelet aggregation}

Platelet aggregation was measured by Born's method [7]. Venous blood $(5 \mathrm{ml})$ was drawn by the same operator using a $21 \mathrm{G}$ needle and a vacuum tube containing a $3.8 \%$ sodium citrate solution $(1: 10$, $\mathrm{V} / \mathrm{V}$ ). Platelet rich plasma (PRP) was prepared by centrifugation at $100 \mathrm{~g}$ for $10 \mathrm{~min}$ at $23^{\circ} \mathrm{C}$. The PRP platelet count was adjusted to $300,000 / \mathrm{mm}$ by addition of platelet poor plasma (PPP) prepared by centrifugation of blood at $300 \mathrm{~g}$ for $10 \mathrm{~min}$ at $23^{\circ} \mathrm{C}$. Platelet aggregation was determined at $37^{\circ} \mathrm{C}$ using a Sienco dual sample aggregation meter (Model DP-247-E, Sienco Institute, Morrison, Colo., USA). All samples of PRP $(250 \mu \mathrm{l})$ were preincubated in polystyrene cuvettes at $37^{\circ} \mathrm{C}$ prior to the addition of aggregating agents. Aggregation was measured at $37^{\circ} \mathrm{C}$ while stirring with a magnetic stir bar at a speed of 1,100 rpm. Aggregating agents (platelet aggregation reagent kit No.885, from Sigma Chemical Co., St.Louis, Mo., USA) were added to $250 \mu \mathrm{l}$ of PRP to reach a final concentration of $1 \mu \mathrm{mol} / 1$ and $2 \mu \mathrm{mol} / 1$ for adenosine diphosphate (ADP), $1 \mu \mathrm{g} / \mathrm{ml}$ for collagen and $2.7 \mu \mathrm{mol} / 1$ for epinephrine. The maximum aggregation was assessed by measuring the highest peak of aggregation curve during $6 \mathrm{~min}$ and expressed the percentage transmission based on $0 \%$ of PRP and $100 \%$ of PPP. All procedures were completed within $2 \mathrm{~h}$ of the blood sampling.

\section{Lipid quantification and insulin levels}

Total plasma cholesterol and triglyceride were measured by SMAC Auto Analyzer (SMAC, Technicon, Tokyo, Japan). Plasma free fatty acid was measured by an enzyme assay [8] and insulin by a doubleantibody radioimmunoassay technique [9].

\section{Statistical analysis}

All values are expressed as mean $\pm \mathrm{SD}$. The values before and after the clamp were compared using the paired Student's t-test [10].

\section{Results}

Blood glucose, insulin, triglyceride, free fatty acid and total cholesterol levels

The levels of blood glucose, insulin, triglyceride, free fatty acid and total cholesterol in the $4 \mathrm{~h}$ saline and insulin clamp sera are listed in Table 1 . During the insulin clamp, insulin levels were approximately 10-fold higher than base levels, while the blood glucose levels remained constant. The triglyceride and free fatty acid levels decreased with time. There were no alterations in total cholesterol levels. Saline infusion did not alter the blood glucose, insulin, triglyceride, free fatty acid or total cholesterol levels during the study.

\section{Platelet aggregation induced by $A D P$, collagen and epinephrine}

Platelet aggregation induced by $1 \mu \mathrm{mol} / 1$ and $2 \mu \mathrm{mol} / 1$ ADP, $1 \mu \mathrm{g} / \mathrm{ml}$ collagen and $2.7 \mu \mathrm{mol} / 1$ epinephrine 
during insulin and saline infusion is shown in Table 2. Insulin infusion tended to inhibit platelet aggregation induced by $1 \mu \mathrm{mol} / \mathrm{l}$ ADP, $1 \mu \mathrm{g} / \mathrm{ml}$ collagen and $2.7 \mu \mathrm{mol} / 1$ epinephrine in time-dependent manner and significant decrease was observed with $1 \mu \mathrm{mol} / 1 \mathrm{ADP}$ $p<0.05,1 \mu \mathrm{g} / \mathrm{ml}$ collagen $p<0.02$ and $2.7 \mu \mathrm{mol} / 1$ epinephrine $p<0.01$ at $4 \mathrm{~h}$ after the start of insulin infusion. The degree of platelet aggregation reduction for $1 \mu \mathrm{g} / \mathrm{ml}$ collagen and $2.7 \mu \mathrm{mol} / 1$ epinephrine was similar. Platelet aggregation induced by $1 \mu \mathrm{mol} / 1 \mathrm{ADP}$, $1 \mu \mathrm{g} / \mathrm{ml}$ collagen and $2.7 \mu \mathrm{mol} / 1$ epinephrine in the $4 \mathrm{~h}$ sample was significantly reduced from the preclamp value of $8.4 \%$ to $3.9 \%(p<0.05), 26.2 \%$ to $7.0 \%$ $(p<0.01)$ and $31.8 \%$ to $9.1 \%(p<0.01)$, respectively. When these are expressed in terms of reduction percentages, the aggregation induced by $1 \mu \mathrm{mol} / 1 \mathrm{ADP}$, $1 \mu \mathrm{g} / \mathrm{ml}$ collagen and $2.7 \mu \mathrm{mol} / 1$ epinephrine was reduced by $50 \%, 73.1 \%$ and $71.4 \%$, respectively, when the values of the pre-infusion were considered as $100 \%$. In contrast, saline infusion did not alter the aggregation induced by $1 \mu \mathrm{mol} / 1 \mathrm{ADP}, 1 \mu \mathrm{g} / \mathrm{ml}$ collagen or $2.7 \mu \mathrm{mol} / 1$ epinephrine. No difference in platelet aggregation was observed between pre-saline and pre-insulin infusions.

\section{Discussion}

Previous reports have noted concomitant improvement of platelet aggregation abnormalities in diabetic patients on insulin with good blood glucose control [3-5]. In the present study, the effect of insulin on platelet aggregation at constant plasma glucose levels was examined. It was found that, $2 \mathrm{~h}$ after the start of insulin infusion, a significant reduction of the ADP-induced platelet aggregation was observed. Four hours after the start of insulin infusion, there was a significant reduction of the platelet aggregation induced by all four agents. The blood glucose level was kept constant during the duration of experiments, but the triglyceride and free fatty acid levels decreased by a time-dependent manner. The cause and effect relationship between the antilipolytic effect and the decreased platelet aggregation could not be statistically established, since the individual value on the reduction in the free fatty acid level at $4 \mathrm{~h}$ after the start of insulin infusion did not significantly correlate with the individual reduction percentage of the epinephrine-induced platelet aggregation at $4 \mathrm{~h}$ after the start of insulin infusion.

The onset of recognisable effects after the start of insulin infusion appear to vary with the parameter examined. Hassanein et al. [11] have reported that the delay in diabetic platelet disaggregation returned to normal at $30 \mathrm{~min}$ after an intravenous injection of insulin. The decreased erythrocyte deformability in diabetes has been shown by Vague et al. [12] to improve with a 2-h insulin infusion. A significant enhancement of low density lipoprotein receptors in normal human mono- cytes [13] and enhancement of lipoprotein lipase activity in normal human adipose tissue [14] has been observed at 4 or $6 \mathrm{~h}$, respectively, after the start of insulin infusion. Alterations which are recognisable within a short time after the start of insulin infusion, such as the improvement of platelet disaggregation [11], the increase of erythrocyte elasticity [12] and the decrease of plasma triglyceride and free fatty acid levels, may be due to a direct action of the infused insulin. The delayed effects of insulin on the reduction of induced platelet aggregation, the enhancement of low density lipoprotein receptors in human monocytes [13] and the enhancement of lipoprotein lipase activity in human adipose tissue [14] may be mediated through other metabolic factors. The ability of ADP, collagen and epinephrine to induce platelet aggregation were equally reduced with the insulin infusion. As these agents can be expected to interact with independent sites on the surface of a platelet, it is unlikely that insulin competes in a similar manner for all those different sites. It is more likely that insulin exerts its effect on a metabolic pathway which leads to aggregation of platelets. One possible site that insulin may interact with is the pathway of thromboxane synthesis since McDonald et al. [3] reported that enhanced thromboxane production in diabetic platelet was normalized by good control of blood glucose using continuous insulin infusion. In the present study, it remains unresolved as to whether insulin directly modulates platelet enzymes or affects the binding sites of aggregating agents on the membrane of platelet.

It has been reported that insulin treatment normalises the altered function of platelets in diabetic patients only when there is strict glucose control [3-5]. It is possible that hyperglycaemia counteracts the effect of insulin on platelet aggregation. We have not examined the effect of insulin on platelet aggregation in presence of hyperglycaemia; nevertheless, it can be concluded that hyperinsulinaemia reduces platelet aggregation in the presence of euglycaemia.

Acknowledgments. We wish to thank Mr. T. Kawada and Mr. H.Ono for their technical assistance. This study was partially supported by a grand-in-Aid for research from The Japanese Ministry of Education, Science and Culture (C-61570562), a grant from The Japan Heart Foundation and a grant from The Arima Memorial Foundation for medical research.

\section{References}

1. Colwell JA, Nair RMG, Halushka PV, Rogers C, Whetsell A, Sagel J (1979) Platelet adhesion and aggregation in diabetes mellitus. Metabolism 28: 394-400

2. Sagel J, Colwell JA, Crook L, Laimins M (1975) Increased platelet aggregation in early diabetes mellitus. Ann Intern Med 82: 733-738

3. McDonald JWD, Dupre J, Rodger NW, Champion MC, Webb CD, Ali M (1982) Comparison of platelet thromboxane synthesis in diabetic patients on conventional insulin therapy and continuous insulin infusions. Thromb Res $28: 705-771$ 
4. Giugliano D, Misso L, Tirelli A, Coppola L, Pinto PD, Torella R (1982) Platelet aggregation after strict metabolic control using the artificial pancreas. Diabetologia 23: 545

5. Evans RJ, Lane J, Holman RR, Turner RC (1982) Induced basal normoglycemia and altered platelet aggregation in non-insulindependent diabetes. Diabetes Care 5: 433-437

6. DeFronzo RA, Tobin JD, Anders R (1979) Glucose clamp technique: a method for quantifying insulin secretion and resistance. Am J Physiol 237: E214-223

7. Born CVR (1962) Aggregation of blood platelet by adenosinediphosphate and its reversal. Nature 194: 927-929

8. Takahashi J, Fujii K, Hayashi C (1975) An approach to develop a new enzymatic method for determination of free fatty acid-preliminary report. Jpn J Clin Chem 4: 179-185

9. Morgan CR, Lazarow A (1963) Immunoassay of insulin: two antibody system. Diabetes 21: 115-126

10. Snedecor GW, Cochran WG (1967) Statistical Methods. Iowa State University Press, Iowa City, pp 93-99

11. Hassanein AA, El-Garf ThA, El-Baz Z (1972) Platelet aggregation in diabetes mellitus and the effect of insulin in vivo on aggregation. Thromb Diath Haemorrh 27: 114-120
12. Vague P, Juhan I (1983) Red cell deformability, platelet aggregation and insulin action. Diabetes 32: 88-91

13. Mazzone T, Foster D, Chait A (1984) In vivo stimulation of low density lipoprotein degradation by insulin. Diabetes 33: 333-338

14. Sadur CN, Eckel RH (1982) Insulin stimulation of adipose tissue lipoprotein lipase: use of the euglycemic insulin technique. J Clin Invest 69: 1119-1125

Received: 29 July 1986

and in revised form: 24 March 1987

Dr. Kazuko Hiramatsu

Department of Internal Medicine

School of Medicine

Tokai University

Isehara, Kanagawa, 259-11

Japan 